
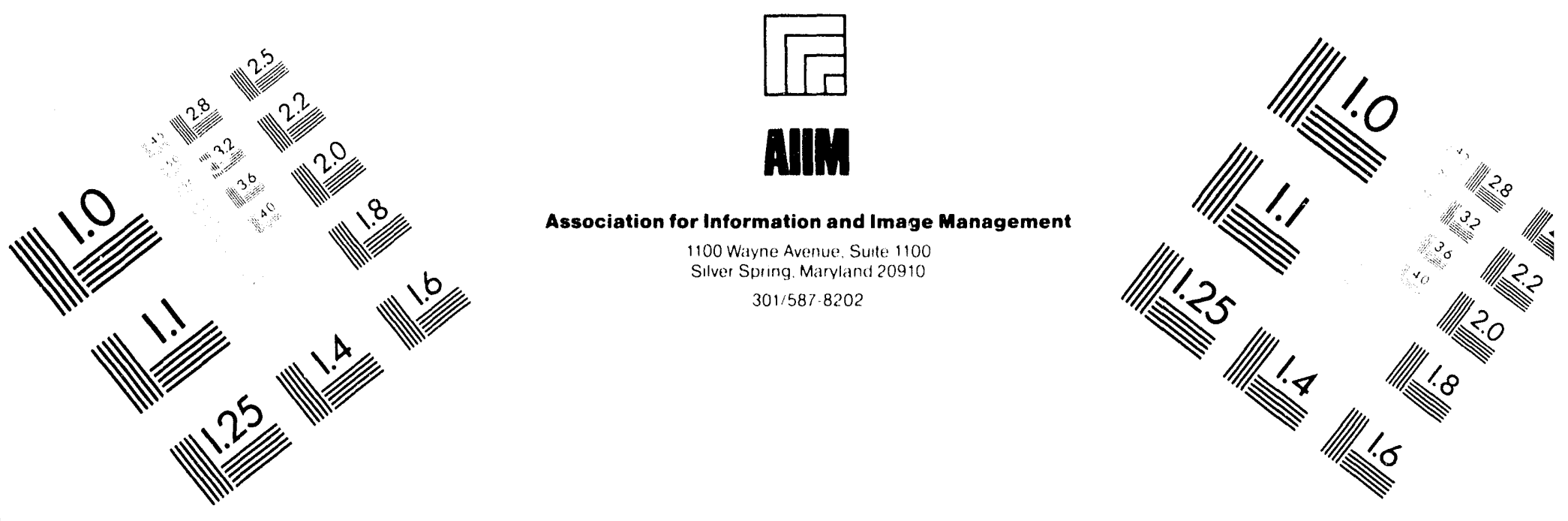

\title{
Centimeter
}

${ }_{1}$

Inches
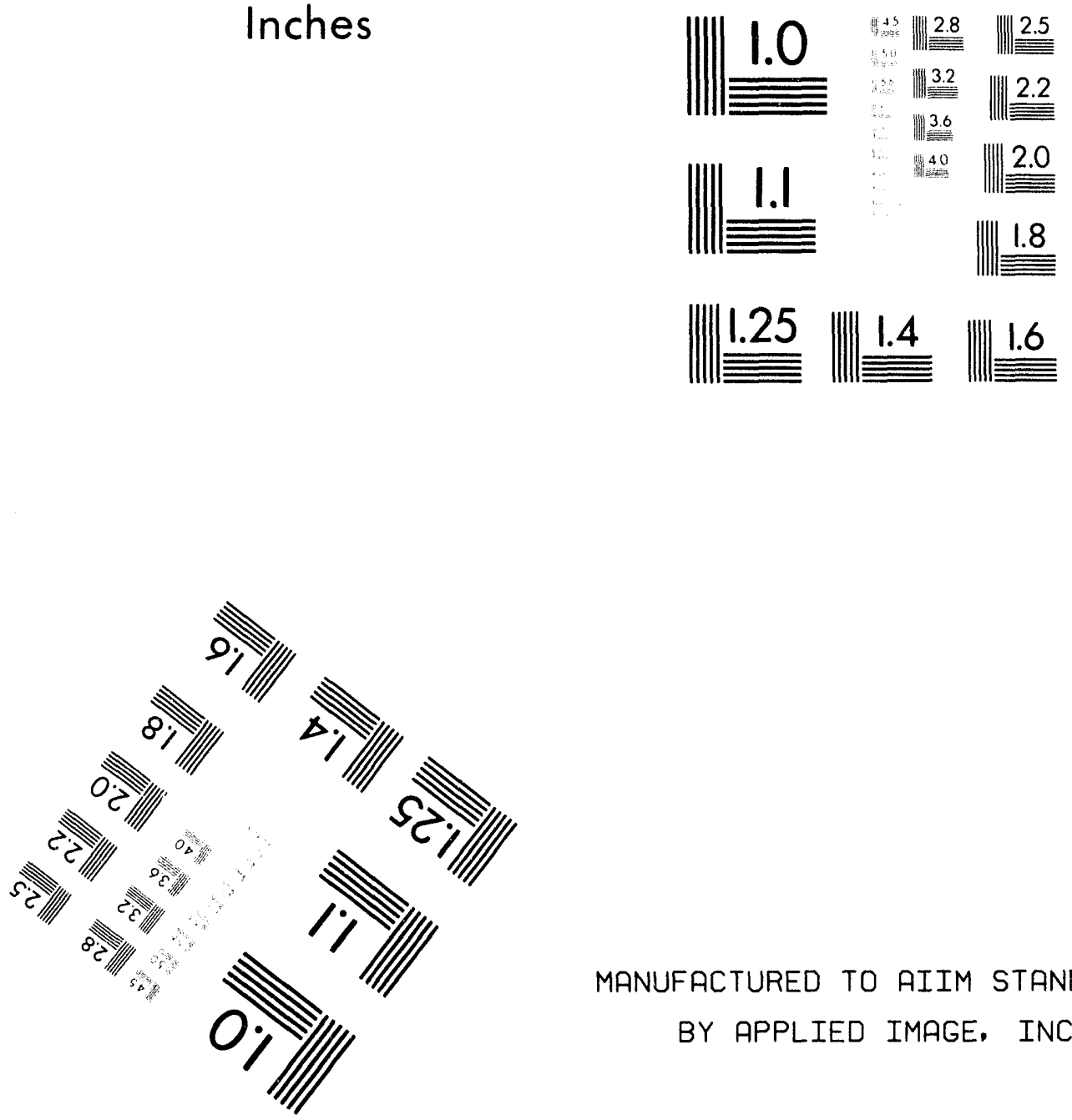

MANUFACTURED TO AIIM STANDARDS

BY APPLIED IMAGE. INC.

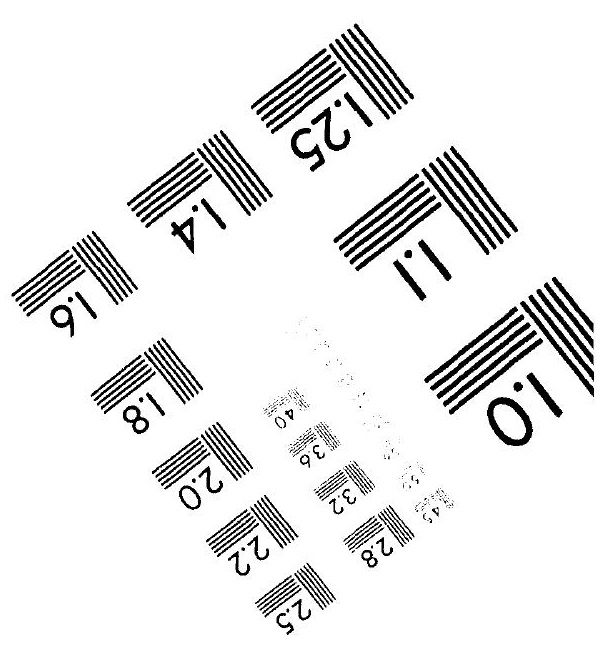



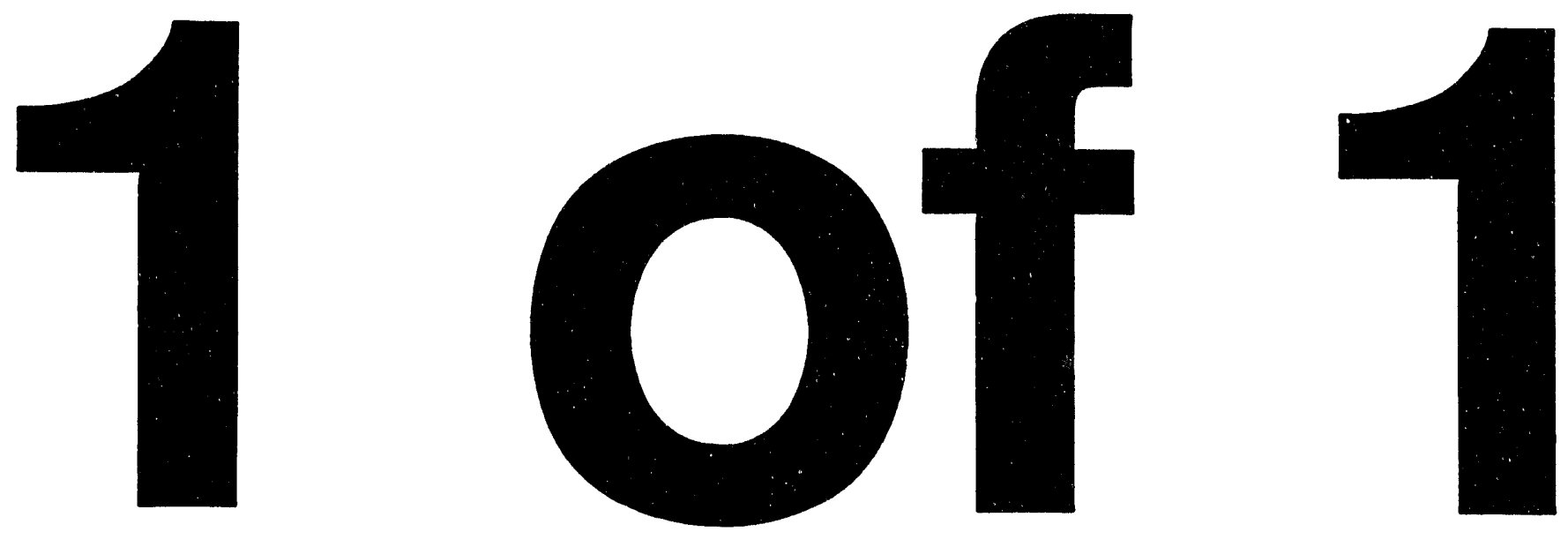


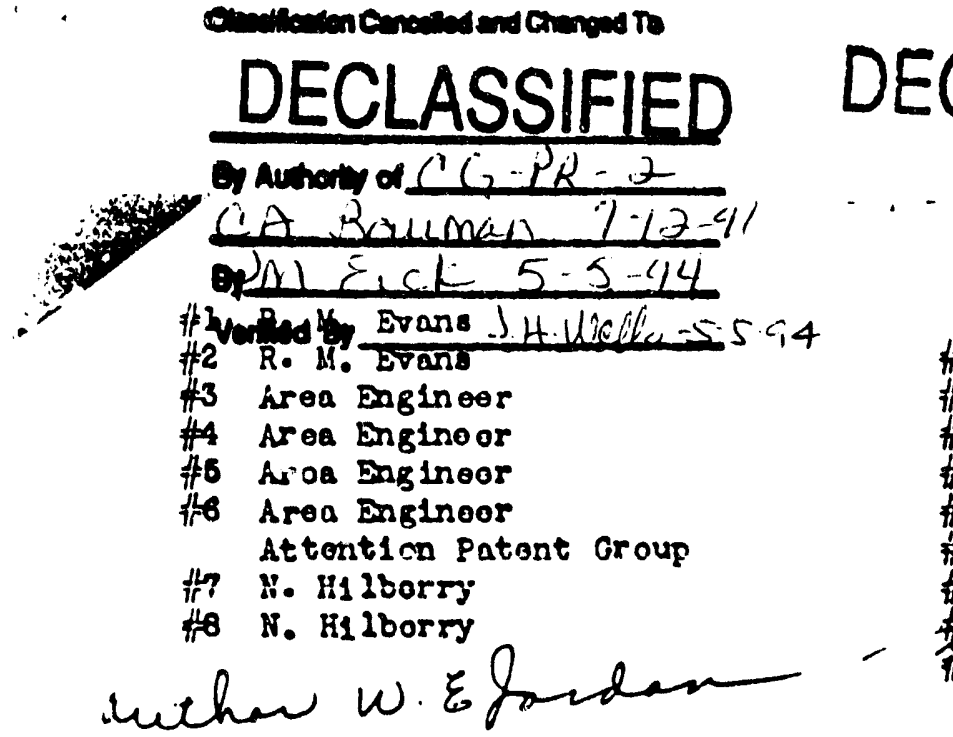

100 AREAS:

July 16 through July $22^{-4}$

(For Tochnical Progross Lotter No. 107)

Phys 100

D P110

The D P1 Io was shut down for about 21 hours on July 16. Throughout two romaindor of this porlod, it opuratod at ratod lovol.

Special Requast 15-2, (11thiun Iluorilie), was chargad into Tubo 2622 turing th1s shutdow. The spocial chargo conslatod of $36 \mathrm{p} 10008$ oach about $3-3 / 4$ inchos long oonterod in tho tubo with jacktod lund ploos. It nas ostimatod ta tavo a. noninal poison valuo of 52 inhours and roplocod a poison oolurm of 51 lnt: :urs noninal strongth. Obsorved ronctifity changos woro in olnoo agroonent with pryis=:1ons.

Os July 18 tho thomocouplo in the A Tost Holo bocamo orratic. S1=liar difflcultius had boon onesuntorod with two provlous thormocouplos and had bos. sttributod to corrosion causod by jampnoss in tho holo. On tho sane day. a s low wht:e loak was notod around tho B Tost Holo nssombly. During tho shutdom schodulod for jyly 23 , it 1s plannod to ranovo tho frant and of tho assonbly ard cotormino if tho wetsr loak 18 in the piping conncetions at tho outsito af the plio or in tho contral part of tho asscmbly.

\section{F P10}

At the hutdown of July 17 the throo vortical rods which did not furstion properly at the provious shutdom wore examinod. It was found that tho e1spiculty in inthdrawing those rods was du. to slipping clutch:0s. Tho olutchos wers rondjustod to thoir original oloarancos.

There whs no not chnnge in the ronctiflty of tho unit during the weex; tho fains during normal oporation just oomponsated tho 10880 duo to the netal dischargod on July 17 .

\section{Gonoral}

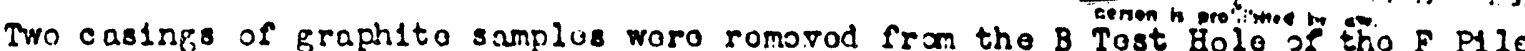
on July 17 aftor totnl oxposurus of 920 and 188 IW-lays/CT, ruspoctivoiy. Tho firat oasing was oxposod 757 itr-days/CT at armblant F Pilo tomporaturos plus les itw-ilays/ CT nftor cooling was nppliod to the tiat holo. The socind casine was exp:sod 39 lNwa

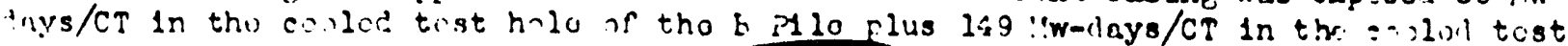




\section{DECLASSIFIED}

holo of tho P1lo. In masurumonts havo boon nado on thoso canplos.

Durthor axporimonts on tho propagation of thumal disturbanoos in graphito of 407 I: that undor ravorablo conlitions (amblont tomporaturo $100^{\circ} \mathrm{C}$. bath tomperaturo about $500^{\circ} \mathrm{C}$ ) tho proph1to tomporaturn can bo mallo to pass through a snall tronslont maximum of tho ordor of $6^{\circ} \mathrm{C}$. aboro its final atoady-atato tanporature. Tho storod onorgy. howernr, nepoars to mnko only a small oontrliutlon to the rnlmelty nt whioh the tisturbanco 18 propagntod. Tho volocity is of tho magnitudo prodictod an tho basis of tho thornal diffusivity of tho matorlal, nanoly, about $0.06 \mathrm{~cm} / \mathrm{so0}$. at ono cunt1motar fron tho orligin of tho disturbanco, and docraasos with incroasinf distanco Sasin tho ortindis.

Arnonling oxporinonts on $1007 \mathrm{lim}$-days/CT graphito which oxpandod $0.77 \%$ lurl:2B Irradiation sharal that in a carban diaxido atmosphoro tho rocorory in longth crouctod to $16 \%$ artor 112 hours at $425^{\circ} \mathrm{C}, 26 \%$ aftor an additional 24 hours at $600^{\circ} \mathrm{C}$, and $38 \%$ nftor furthor hoating ut $600^{\circ} \mathrm{C}$ for 168 hours. No crumbling was notod. In alr, tho rocovory was $58 \%$ aftor 112 hours at $425^{\circ} \mathrm{C}$, whth vory slight surfaco roughaning, and 60; aftor an anditional 24 hours at $600^{\circ} \mathrm{C}$ wh nociornto surfaco rouphoning. In additional 168 hours at $600^{\circ} \mathrm{C}$ produocd omplito orumbling.

\section{ilator, Corrosion and Englnoorinf}

\section{Proooss Mator Control ard Prossuro Drop Studios}

Tho 1ron contont in tho procoss wator arnragod $0.031,0.009$ and 0.010 ppr. at B, $D$ and F Nroas, rospootivoly. Thoso valuos aro about tho samo is thoy havo boon for tho past sovoral rooks.

Tho ratos of prossuro cirop 1110 ronso for $D$ ant $F$ Arous woro 0.11 and $0.34168 . /$ (sq. in.) (day), raspoctiroly.

\section{Gorrosion}

Cast matorlal fra Tubo 2363 was disohargod at $F$ on July 3 to oxanino tho sluf; for blistoririf ast to dotormino tho corrosion rato of thoso slugs. Cno olug fron this tubo appoarod to bo slightly bl1storod. It ras uncopootod to rind ollstorod slui:s in this tubo and in Tubo 2063 at D, A1schargod July B, bocauso of tholr rolativoly low axposuro. Graflmotr1c data :or Tubo 2363 at F aro oummarlsod bolow:

\begin{tabular}{|c|c|c|c|}
\hline \multirow{3}{*}{ Exposuro, days } & \multicolumn{3}{|c|}{ Corrosion Data, Tubo $2363 \mathrm{~F}$} \\
\hline & recumulatod powor. & Ponotration & Roto, in./no. \\
\hline & IITD & Avernfo & linxinun \\
\hline 92 & 11 & 0.00004 & 0.00007 \\
\hline
\end{tabular}

Thoso panetration rates aro normal. No unusual oorrosion was notod an any of tho sluge.

\section{Grophito Exparsion}

At tho timo of tho B shutdom in March, tho intornal distanoo betwoan straps on tho nooprcnu soal at tho far 1 ito was as much as 3-3/4 inchos. Rocont strotch tosts on a samplo of nooprano takon from tho middlo of tho seal otrip artor it had boon raplacod showal that tho nooprono booano taut when the width hotwonn tio strips was $2-1 / 2$ inohos and fnilos whon stretohed to $4-1 / 2$ inches. Sinco tho strotch tost doos 


\section{DECLASSIFIED}

not duplicato tho rate of atrotching by tho pllo, and sinoo tosts on a samplo from the nooprane strip ut $D$ showod ralluro after $35 \%$ oloncation 1nstoad of tho above $80 \%$ elongation, It 18 cone luriod that nooprono soals aro in dangor of falling soon artar thoy havo boan atrotohed taut.

Push-pull tnats woro ando with tho 1500 1b. pnoumatic jook an $1 x$ tubos at $D$ on July 23. During tho pets tho pletalls wero roplacod with a rukter hose but tho tubce woro not dischergod. Rosults aro glon in tho rollowing tablo.

Iuंง กั०. Gun Barrol Surnel loaranco, in.

Foroe regulfud sar rill \& ropratuoiblo.norcent, 168. Binding
Push-Pull Tosts on Tubes at D

\begin{tabular}{lccccc}
\hline 1474 & 2562 & 2561 & 3474 & 3559 & 4008 \\
$22 / 32$ & $21 / 32$ & $22 / 32$ & $.14 / 32$ & $18 / 32$ & $14 / 32$ \\
& & & & & \\
700 & 900 & 600 & -800 & 800 & $>1000$ \\
110 & No. & No & Y08 & 110 & Y08
\end{tabular}

Tubo 3474 morad $18 / 32$ inch wth a 600 1b. forco tho risst tino it was triod. in subsoquent trials the novoment was roducod to $3 / 32$ inohe. IIth an incroaso of foroo to 800 1b8. a asrasont of oxly $3 / 32$ 1nch cald be obtalnod an two trialos Tho tosts were then discastinuod bocauso of tho probability of lnereasing tho binding inter oonditians of tho tost.

Tubo 4068 could xely be mored $7 / 32$ inch at the front and $4 / 32$ inch at tho roar by a foroc of 1000 128. This tost was not oxtansivo onough to dotoralio whothar or not this hlgh friction mul? inoronso as tho tubo was morod in and out.

Tho data sbtal doc fros tubos whoro bindinf was not enosuztorad aro intondod to provicio a haso for following rubsequent chanfos in olonranco botwoan tho gun barrols and tho frophito. Tho eloarancos moasurod aro comparahlo to those coasurod at $B$ and aro largor than had toon anticipatod carlior this yoar.

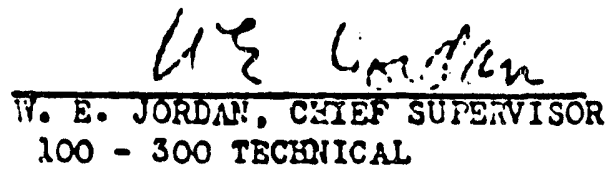

TEJ : $j$ d 

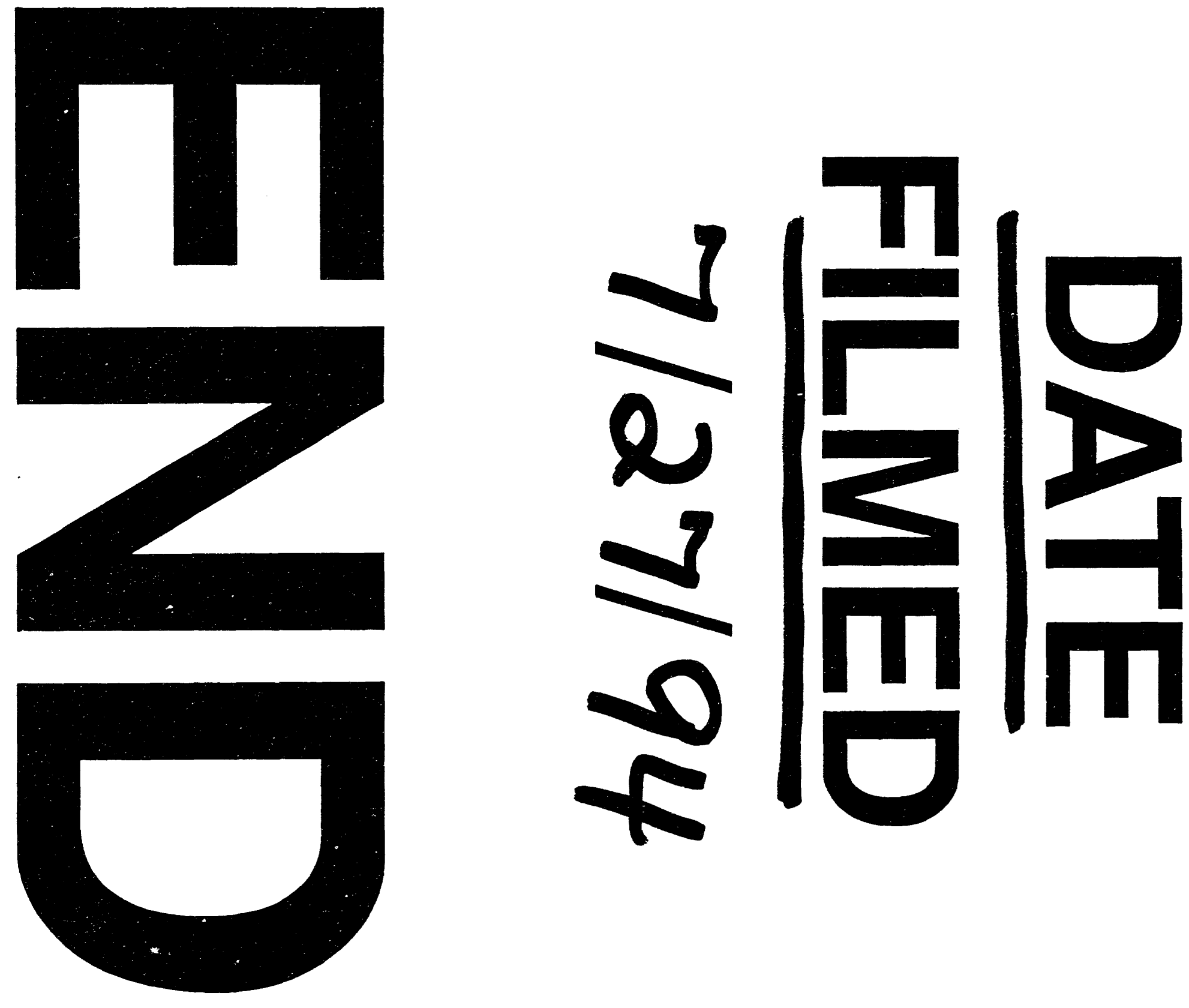

, 